\title{
SUBCUTANEOUS PHAEOHYPHOMYCOSIS CAUSED BY Cladophialophora sp.: A CASE REPORT
}

\author{
Nurimar C. FERNANDES(1), Daniella NACIF(1), Tiyomi AKITI(2) \& Tullia CUZZI(3)
}

\begin{abstract}
SUMMARY
A case of subcutaneous phaeohyphomycosis caused by Cladophialophora sp. is reported. The patient, an immunosuppressed host presented a nodule on the dorsum of the right hand which relapsed four months after excision. Dematiaceous septate hyphal and yeast like elements were seen in mycological and histological examination. The isolated fungus was identified on the basis of micro-macromorphological and physiologic characteristics.
\end{abstract}

KEYWORDS: Mitosporic fungi; Dermatomycoses; Kidney transplantation; Surgery; Immunesuppression.

\section{INTRODUCTION}

The term phaeohyphomycosis has been used for the first time by AJELLO in $1974^{9,10}$ to express one group of mycoses caused by dematiaceous fungi which, in tissue, reveal dematiaceous septate, regular or distorted, toruloid hyphae besides yeast-like cells. It is frequently associated to debilitating chronic diseases, diabetes mellitus or prolonged corticosteroid therapy. The fungi belong to the classes Hyphomycetes and Coelomycetes as well Phylum Ascomycetes. Exophiala jeanselmei, one of the commonest causative agents, is isolated from soil, decaying wood and vegetation. Four clinical forms have been described: superficial, cutaneous and/or mucous, subcutaneous and systemic (brain, eyes, bones, peritoneum).

Clinically the lesion may be mistaken for lipoma, fibroma, epidermal cyst or foreign body reaction. Most of authors state the surgical excision for small lesions.

In the period 1979-2006 only nineteen cases have been described in Brazil. We add to the Brazilian casuistic one case of subcutaneous phaeohyphomycosis with histopathological and mycological diagnosis (Table 1).

\section{CASE REPORT}

A 47-year-old white male stone worker from Rio de Janeiro, came to the outpatient unit of University Hospital Clementino Fraga Filho for the first time in November 2003. He complained about a nodule on the fourth right hand finger which was observed four years ago. He was submitted thirteen years ago to a kidney transplant by hypertensive nephropathy; using regularly prednisone $(20 \mathrm{mg} /$ daily $)$ and azathioprine
(100 mg/daily). We could observe also controlled psoriasis and multiple verrucae in the arms. The asymptomatic nodule $(3 \mathrm{~cm})$ discharged milky material; it was surgically removed and the histological sections revealed phaeohyphomycosis; direct mycological examination disclosed dematiaceous septate hyphae.

In March 2004 the patient observed in the area of surgical scar an increasing volume and in December 2004 returned to the outpatient dermatologic unit. The hand X-Rays and CT did not reveal bone lesions. He was submitted to a large surgical excision on the dorsum of the right hand and fourth finger. The removed nodule averaged $3-4 \mathrm{~cm}$ (Fig. 1).

The direct examination on $\mathrm{KOH} 20 \%$ preparation of the gelatinous aspirated specimen revealed dematiaceous toruloid septate hyphae and budding yeast cells (Fig. 2). The material cultured on Sabouraud Dextrose 4\%, Sabouraud's agar with cycloheximide + chloramphenicol and yeast extract agar incubated at room temperature yielded growth of black cottonous colonies (Figs. 3, 4).

The isolated fungus was identified as Cladophialophora because the primary isolate (PCA, PDA) disclosed absent or underdeveloped conidiophores and unicellular slightly pigmented conidia (Fig. 5). The physiologic characteristics were tolerance to $1 \%$ cycloheximide, growth at $37^{\circ} \mathrm{C}$ and no ability to liquefy gelatin.

Nowadays species of Cladosporium (bantianum, carrionii, devriesii and trichoides) are classified in genus Cladophialophora (Table 2).

Stained section of the skin lesion demonstrated a chronic inflammatory granulomatous process with multinucleated giant cells

(1) Serviço de Dermatologia, Faculdade de Medicina, HUCFF/UFRJ, RJ, Brasil.

(2) Laboratório de Micologia, HUCFF/UFRJ, RJ, Brasil.

(3) Patologia, Faculdade de Medicina, HUCFF/UFRJ, RJ, Brasil.

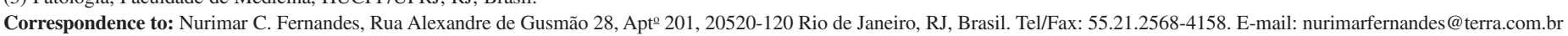


Table 1

Subcutaneous phaeohyphomycosis in Brazil: 1979-2006

\begin{tabular}{|c|c|c|c|c|}
\hline AUTHOR, YEAR & NUMBER OF CASES & CLINICAL FORM & SITE OF INFECTION & CAUSATIVE AGENT \\
\hline Porto et al., 1979 (12) & 1 & - Nodule & Arm & Phialophora bubakii \\
\hline Bambirra et al., 1983 (1) & 4 & - Cyst & $\begin{array}{l}\text { Arm (1) } \\
\text { Leg (3) }\end{array}$ & No culture \\
\hline Castro \& Gompertz, 1984(2) & 1 & Nodule-cystic & Leg & Cladosporium elatum \\
\hline Cucé et al., 1986 (4) & 1 & Nodule & Foot & Exophiala dermatitidis \\
\hline Severo et al., 1987 (13) & 3 & $\begin{array}{l}\text { - Cyst } \\
\text { - Foreing body reaction }\end{array}$ & Foot & Exophiala jeanselmi \\
\hline Fonseca et al., 1990 (7) & 3 & $\begin{array}{l}\text { - Tuberous lesion } \\
\text { - Nodule }\end{array}$ & $\begin{array}{c}\text { Leg } \\
\text { Foot } \\
\text { Hand }\end{array}$ & No culture \\
\hline Costa et al., 1991 (3) & 1 & - Verrucous lesion & Foot & Bipolaris hawaiiensis \\
\hline Zaitz et al., 1997 (15) & 1 & - Nodules & $\begin{array}{c}\text { Hand } \\
\text { Sternal region }\end{array}$ & Phoma cava \\
\hline Cunha Filho et al., 2005 (5) & 2 & $\begin{array}{l}\text { - Nodule } \\
\text { - Papule }\end{array}$ & Foot & Veronaea bothryosa \\
\hline Silva et al., 2005 (14) & 1 & - Multiple nodules & Leg & Exophiala jeanselmei \\
\hline Ferreira et al., 2006 (6) & 1 & - Nodule-cystic & Leg & Exophiala jeanselmei \\
\hline
\end{tabular}
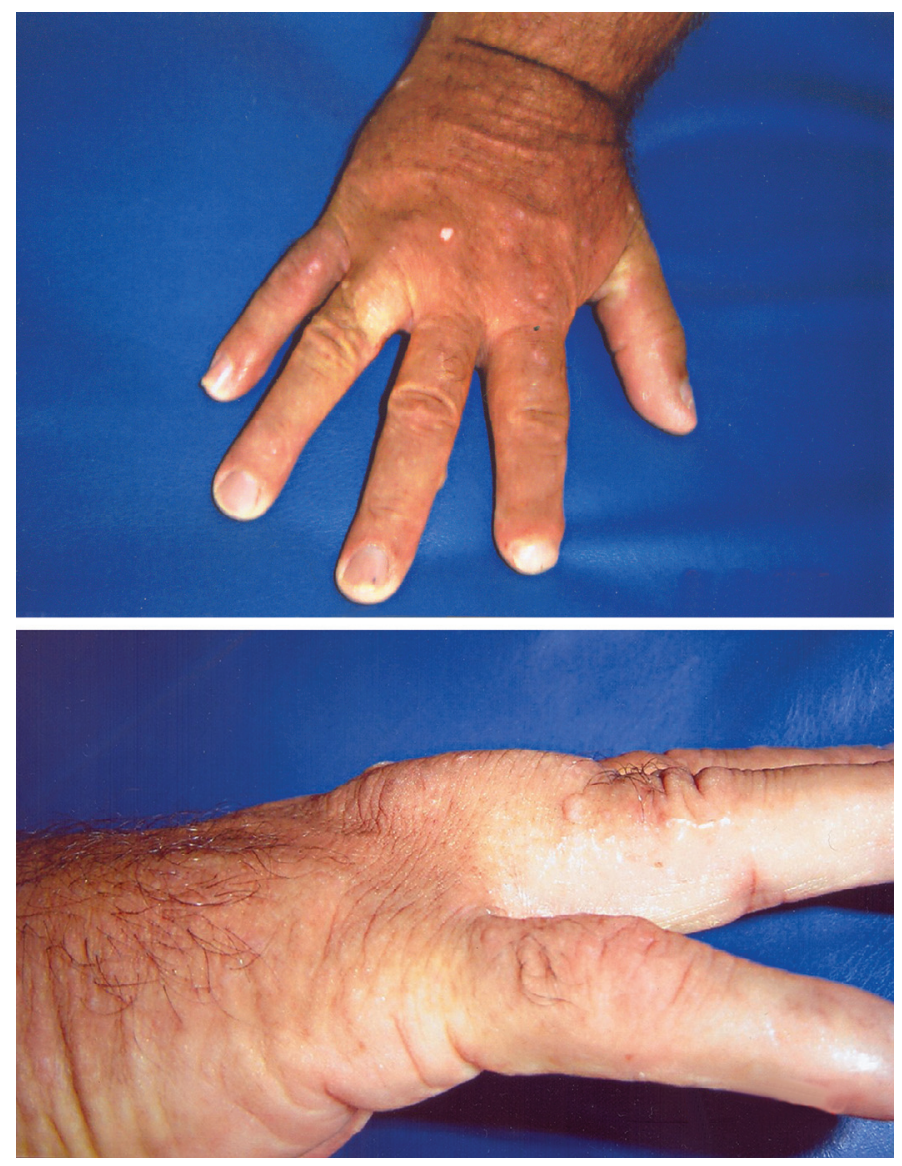

Fig. 1 - Nodule on the right hand dorsum.

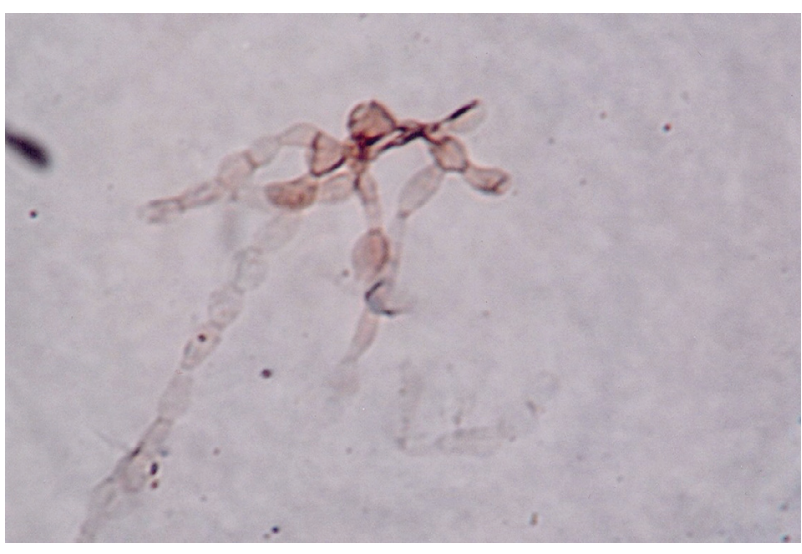

Fig. 2 - Toruloid dematiaceous septate hyphae in the aspirate (KOH 20\%) (60x).

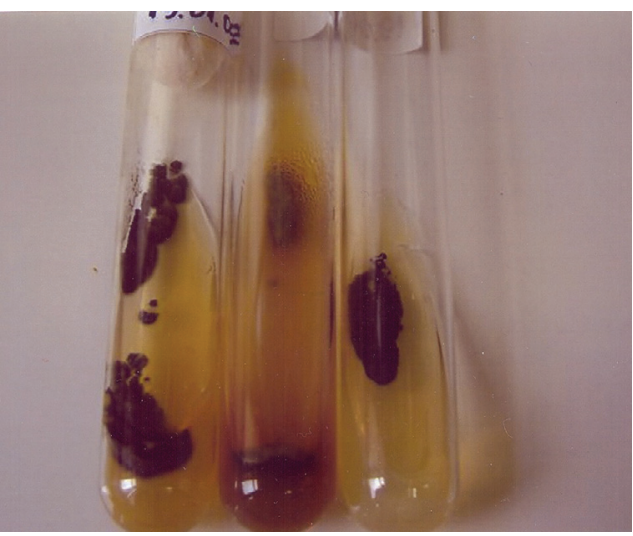

Fig. 3 - Black cottonous colonies (primary isolate). 


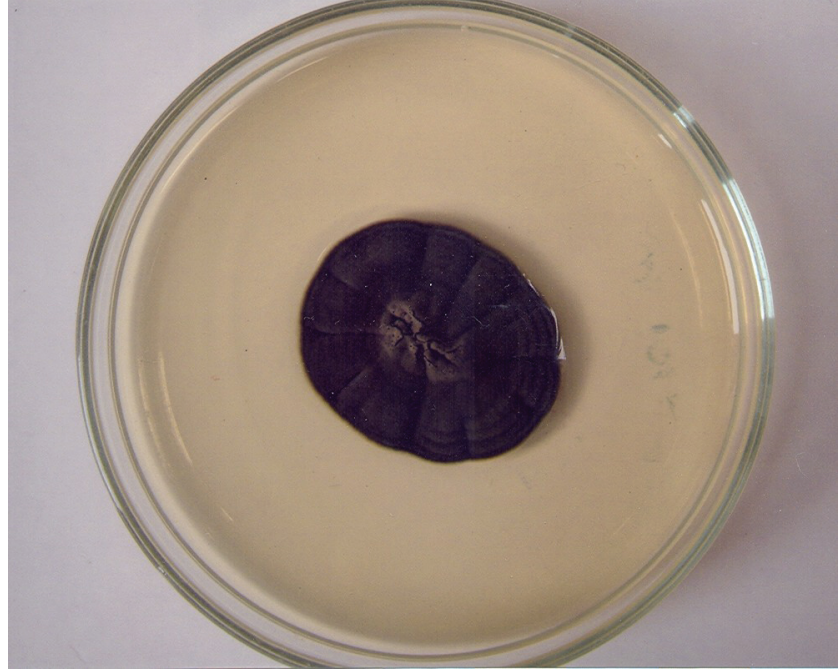

Fig. 4 - Black cottonous colony (sub culture).

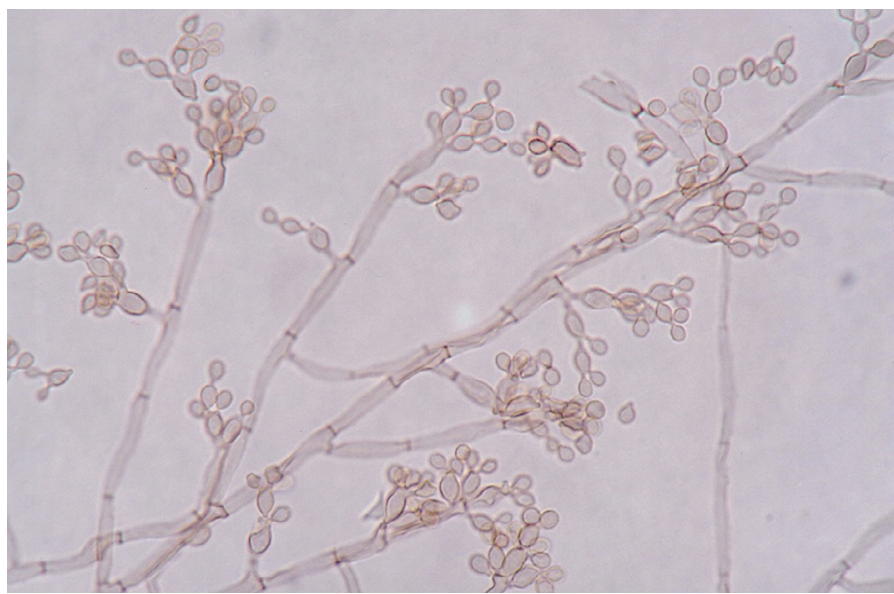

Fig. 5 - Micromorphology: underdeveloped or absent conidiophores, unicellular slightly pigmented conidia of Cladophialophora sp. (60x).

Table 2

Cladophialophora sp. ${ }^{11}$

\begin{tabular}{|c|c|}
\hline CURRENT NOMENCLATURE & SYNONYM \\
\hline Cladophialophora bantiana & $\begin{array}{l}\text { - Cladosporium bantianum } \\
\text { sin Xylohypha emmonsii } \\
\text { - Cladosporium trichoides } \\
\text { sin Xylohypha bantiana }\end{array}$ \\
\hline Cladophialophora boppii & - Taeniolella boppii \\
\hline Cladophialophora carrionii & $\begin{array}{l}\text { - Cladophialophora ajelloi } \\
\text { - Cladosporium carrionii }\end{array}$ \\
\hline Cladophialophora devriesii & - Cladosporium devriesii \\
\hline Cladophialophora modesta & - \\
\hline Cladophialophora arxii & - \\
\hline
\end{tabular}

and neutrophils composing microabscesses. It was observed thick walled brown hyphae mainly disclosed by Fontana-Masson stain (Fig. 6). By HE stain, fungal structures inside giant cells (Fig. 7).

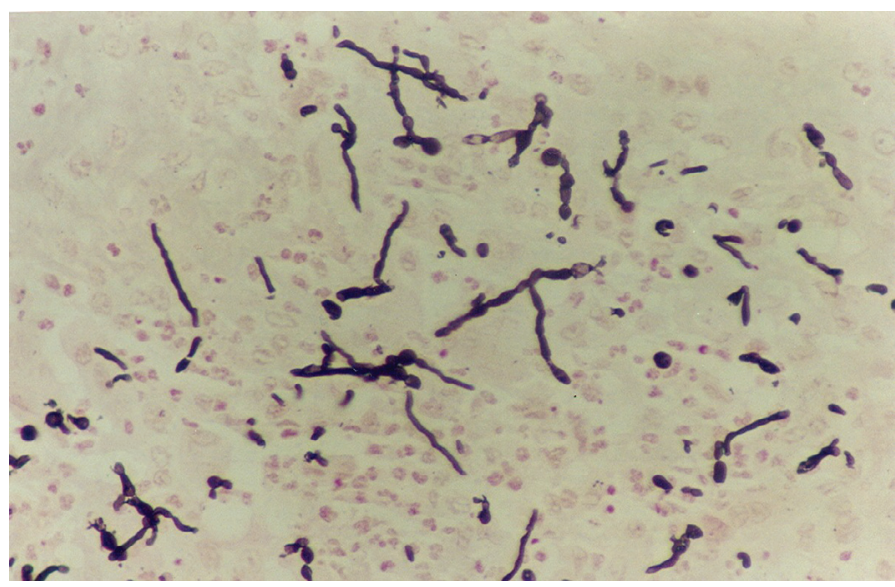

Fig. 6 - Brown fungal structures between the inflammatory cells (Fontana-Masson; 200x)
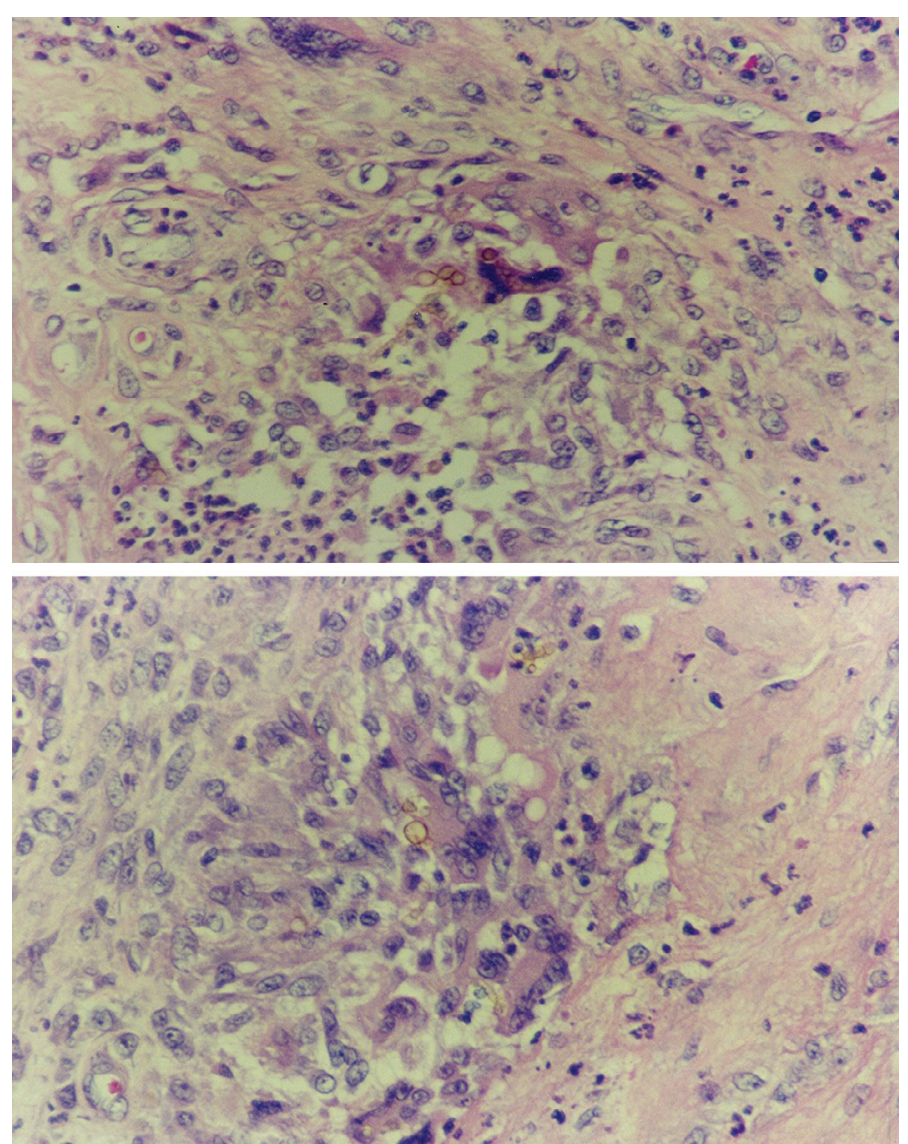

Fig. 7 - Fungal structures inside multinucleated giant cells (HE; 400x).

\section{DISCUSSION}

Clinically, subcutaneous phaeohyphomycosis is characterized by solitary, asymptomatic, discrete and well capsulated nodule ${ }^{7}$. Nodules 
are also described without capsule. It is located everywhere but usually in the extremities; it appears or not after local trauma. Besides arms and legs, other areas of the body may be affected. There is no involvement of the skin and develops with central necrosis which results in abscess ranging from one or more centimeters in diameter with a liquefied center. There is no tendency to spontaneous rupture or fistulae formation. The discharge is purulent, yellow-gray and viscous ${ }^{7}$. The phaeohyphomycosis in renal transplant recipient is well known, for the opportunistic agents in the immunosuppressed patients, establish several infectious diseases ${ }^{1}$. Histologically the abscess is deeply located in the dermis or subcutaneous tissue and is surrounded by a fibrous capsule. Central contents are creamy, viscid with a yellow, tan, brown or gray green color. Sometimes plant fragments may be present in the abscess. The septate, short, branched or not, chestnut brown hyphae are seen in the inner surface of the cyst wall or in the center of the abscess $^{7}$; they vary in length and have a diameter of 2-6 $\mu \mathrm{m}$; they may be short, septate branched or unbranched; thick walled budding cells sometimes in short chains may be noted ${ }^{9,10}$. In the immunosuppressed hosts the lesions use to be less well capsulated and to drain through the fistulae ${ }^{8}$. All dematiaceous fungi are similar and they can't be differentiated in the tissues solely on the basis of morphology. For specific identification culture is needed. Between the reported cases, Exophiala species is the commonest. Immunosuppression or debilitating diseases favor the spreading of the infection but the host's defense mechanisms which contribute to localize the lesion are unknown. There are no available serologic tests. The taxonomy of Cladophialophora is rather confuse. In table 2, the current nomenclature ${ }^{11}$.

The 5-fluocytosine in association with amphotericin B or ketoconazole in association with amphotericin B have been indicated for extensive and deep lesions ${ }^{10}$. We decided for surgery taking into consideration the lack of the 5-fluocytosine and the renal toxicity of amphotericin B. It has been said the ketoconazole is able to cure or to improve few small lesions which were not completely removed but more often the initial improvement is partial and followed by recurrence ${ }^{8}$. We could not find any explanation for the recurrence of some lesions; should the lesion less well capsulated prone to it? In this case the discharge of milky material suggests this point of view. In the follow-up of twenty months the patient has no evidence of relapse.

\section{RESUMO}

\section{Feohifomicose subcutânea causada por Cladophialophora sp.: relato de caso}

É descrito caso de feohifomicose subcutânea causada por Cladophialophora sp. O paciente, imunossuprimido, apresentou nódulo no dorso da mão direita que recidivou quatro meses após excisão. Os exames micológico e histopatológico evidenciaram hifas septadas demácias e células leveduriformes. O fungo foi identificado com base no estudo micro-macromorfológico e fisiológico.

\section{REFERENCES}

1. BAMBIRRA, E.A.; MIRANDA, D.; NOGUEIRA A.M. \& BARBOSA, C.S. Phaeohyphomycotic cyst: a clinicopathologic study of the first four cases described from Brazil. Amer. J. trop. Med. Hyg., 32: 794-798, 1983.

2. CASTRO, R.M. \& GOMPERTZ, O.F. - Feohifomicose subcutânea por Cladosporium elatum. Relato de um caso. An. bras. Derm., 59: 235-237, 1984.

3. COSTA, A.R.; PORTO, E.; TABUTI, A.H. et al. - Subcutaneous phaeohyphomycosis caused by Bipolaris hawaiiensis. A case report. Rev. Inst. Med. trop. S. Paulo, 33: 74-79, 1991.

4. CUCÉ, L.C.; SALEBIAN, A.; PORTO, E.; MELO, N.T. \& LACAZ, C.S. - Feohifomicose em transplantada renal por Exophiala dermatitidis (Kano) de Hoog, 1977. An. bras. Derm., 61: 207-211, 1986.

5. CUNHA FILHO, R.R.; SCHWARTZ, J.; REHN, M.; VETTORATO, G. \& RESENDE, M.A. - Feohifomicose causada por Veronaea bothryosa: relato de dois casos. An. bras. Derm., 80: 53-56, 2005.

6. FERREIRA, L.M.; PEREIRA, R.N.; DINIZ, L.M. \& SOUZA FILHO, J.B. - Qual é o seu diagnóstico? Feo-hifomicose. An. bras. Derm., 81: 291-293, 2006.

7. FONSECA, A.P.M.; FONSECA, W.S.M.; SILVA, J,G. et al. - Feohifomicose subcutânea: relato de três casos. An. bras. Derm., 65: 303-307, 1990.

8. KWON-CHUNG, K.J. \& BENNETT, J.E. - Phaeohyphomycosis. In: KWON-CHUNG, K.J. \& BENNETT, J.E. Medical Mycology. Philadelphia, Lea \& Febiger, 1992. p. 620-677.

9. LACAZ, C.S.; PORTO, E.; ANDRADE, J.G. \& TELLES FILHO, F.Q. - Feohifomicose disseminada por Exophiala spinifera. An. bras. Derm., 59: 238-243, 1984.

10. LONDERO, A.T. - Feo-hifomicose: interesse em dermatologia. An. bras. Derm., 62: 327-331, 1987.

11. McGINNIS, M.R.; SIGLER, L. \& RINALDI, M.G. - Some medically important fungi and their common synonyms and names of uncertain application. Clin. infect. Dis., 29: 728-730, 1999.

12. PORTO, E.; LACAZ, C.S.; SABBAGA, E. et al. - Phialophora bubakii. Isolamento de abscesso subcutâneo em transplantado renal. Rev. Inst. Med. trop. S. Paulo, 21: 106-109, 1979.

13. SEVERO, L.C.; GEYER, R.; SOUZA, A.L. \& BALBINOTTI, M. - Feo-hifomicose subcutânea: relato dos três primeiros casos do Rio Grande do Sul, Brasil. An. bras. Derm., 62: 37-40, 1987.

14. SILVA, M.R.R.; FERNANDES, O.F.L.; COSTA, C.R. et al. - Subcutaneous phaeohyphomycosis by Exophiala jeanselmei in a cardiac transplant recipient. Rev. Inst. Med. trop. S. Paulo, 47: 55-57, 2005.

15. ZAITZ, C.; HEINS-VACCARI, E.M.; FREITAS, R.S. et al. - Subcutaneous phaeohyphomycosis caused by Phoma cava. Report of a case and review of the literature. Rev. Inst. Med. trop. S. Paulo, 39: 43-48, 1997.

Received: 10 November 2005

Accepted: 22 September 2006 